\title{
Evaluation of factors responsible for waste and environmental impacts arising from the production of meals in food services
}

\author{
Mario dos Santos BULHÕES ${ }^{1 *}$ (D), Maria da Conceição Pereira da FONSECA², Darlan Azevedo PEREIRA ${ }^{3}$, \\ Márcio A. F. MARTINS ${ }^{1}$
}

\begin{abstract}
Food services establish an important link with the food production chain, not only from the economic point of view, but also associated with the environmental impacts resulting from their activities. This paper deals with an analyze of publications from 2009 to 2019 on factors responsible for waste generation and sustainability in food services. The results show that food waste occurs in a systematic and multifaceted way, requiring a broader and interdisciplinary approach, not only considering the measurement of waste, but also the complexity involved in the production and processing of collective meals. Finally, it is clear that a great part of the studies focuses on the generation of knowledge about the problem of waste and its quantification, evidencing a lack of studies aimed at the use and improvement of tools, techniques and methods concerning the identification and control of factors responsible for the generation of waste at its origin. These results contribute to the food science to emphasize the need for more assertive propositions to control and mitigation of food waste taking into account the total complexity involved in its generation in commercial and institutional food services.
\end{abstract}

Keywords: food services; food waste; sustainability; waste reduction; catering.

Practical Application: This study highlights a better understanding of the variables responsible for waste generation at their origins, to the management and control of food waste in food service.

\section{Introduction}

Food services establish a link with the Food Supply Chain (FSC), not only from an economic standpoint, but also associated with the environmental impact of its activities. The waste index of food genres and resources along the stages of Garnett (2011) in food services generates an unnecessary demand in the FSC, implying in the overuse of fertilizers and pesticides, as well as utilities destined to planting activities: electricity, water and fuel for harvesting, transport and storage (Proença, 2000).

Some problems as the increased greenhouse gas emissions and as well as compromising water supply for human consumption and animal husbandry are cited by FAO as impacts caused by food loss and waste (Flammini et al., 2013). Researches carried out by Godfray et al. (2010) cites some negative externalities caused by the loss and waste of food include: ecotoxicity by pesticide use, eutrophication and soil erosion, loss of organic matter and biodiversity.

The inadequate of disposal of products and packaging generated by the food services through the adherence of efficient policies for solid waste management (Abreu \& Pinto, 2009) and the use of non-biodegradable chemicals associated with waste of water and energy compromise the environment (Proença et al., 2005).

Studies performed by Rand \& Nowak (2013) state that the most of students who live on the university campus are benefited by financial aid for food or the cost of your meals are paid by their parents which reduces the financial responsibility of diners, promoting the wastage practices. To Lagorio et al. (2018) most consumers perceive waste as an inevitable fact, in this way they believe that the act of wasting is common and they do it. This fact taunting the increase in the number of discussions between researchers (Pinto et al., 2018).

Studies conducted by Quested et al. (2013) cities that the behavioral issue involved in food waste is usually not related to preventive aspects but to individual habits which are marked by a pronounced emotional component, similarly (WRAP, 2016) cities that it is necessary to adopt policies aimed at consumer awareness in the waste prevention process Grandhi \& Appaiah Singh (2016) draws attention to the lack of methods in food classification, as well as the lack of food awareness, otherwise Parizeau et al. (2015) emphasize that the presence of food awareness, as well as convenience related with lifestyle, are directly associated with the generation of waste.

Other studies have assessed that certain interventions aimed at raising awareness do not sufficiently reduce food waste (Watson \& Meah, 2013). These results converge with the studies conducted by Evans (2012) which proposes that efforts to reduce food waste being directed to material aspects related to food packaging, size, shape as well related to the facilities in infrastructure. 
The use of good practices aimed at reducing the environmental impacts within the food services is considered a promoter of sustainability. The adoption of measures such the use of traceable food from agroecological farming, as well as the training of employees involved with the production of meals and implementation of environmental protection policies contributes directly to the sustainability process within the food services (Martinelli, 2011).

More sustainable practices, besides contributing to environmental improvement, are also perceived as an instrument that assists the competitive advantage of companies (Azapagic, 2003) for that reason it is necessary to develop a structural model focused on the sustainability of its actions, which meets the needs and attributes of its customers and other stakeholders (Hynds et al., 2014) where this model is likely to take an eco-design approach (Short et al., 2012).

Although there has been an increase in research on food waste generation, the focus of most of this research has been on retail and households, not including the hospitality and food serving sectors (Papargyropoulou et al., 2014). Besides, the absence of new approaches and the use of new integrated tools for waste generation and environmental impact assessment makes it difficult to advance and improve new, more efficient methods (Baldwin et al., 2011).

The Authors' map highlights visually to the readers in its three main axes: Underlying factors; Sustainability and Use methodologies and tools, the focus and objective of the research conducted over the past ten years related to the problem of food waste and its associated environmental impacts in the Food Service sector. Understanding the factors associated with the practice of waste, as well as its causal and interdependent relationships is fundamental to mitigate food waste, however, this work clearly highlights a gap in studies and research related to aspects of this nature.

It is also evident that most of the studies that focus on the analysis and control of waste are limited to quantifying waste in order to compare them with values recommended by the literature. Given this, it is possible to understand the need to develop researches that consider broader approaches, taking into account the hidden complexity in the causes or reasons of the waste generation. The adoption of tools and methodologies such as Cleaner Production approach, Structural Equation analysis, System dynamics, etc. can contribute significantly to conducting new research to break current paradigms.

From the foregoing context, this work aims at addressing a systematic way the main factors associated with the generation of waste food, the use of methodologies and tools for its control and minimization, as well as the environmental impacts resulting from these wastes, as well as, providing subsidies to the Food Services to set goals and promote initiatives aimed at improving their production processes.

\subsection{Differences between "food loss" and "food waste"}

The definitions used for food residues vary according to when they were generated, and they differ universally in their concept (Lebersorger \& Schneider, 2011). For Buzby \& Hyman (2012) this divergence hinders the study and quantification of food residues. Different categories are created based on the type of food stuff, means in which they were produced, and management approaches (Gjerris \& Gaiani, 2013). Some terms have been used alternatively by some authors, to define edible foods discarded in the trash such as: loss of food, waste, food waste, among others (Schneider, 2013). According to Gjerris \& Gaiani (2013) this multiplicity of terms and definitions for a type or class of residue, in the case of organic residues, ends up causing a lot of confusion among the researchers focused on the subject.

An extensive part of the literature addressing prevention issues for food waste subdivides food wasted in two categories: a part that focuses on preventive measures and other part that does not. These categories are composed of the "avoidable/Edible" and "non-avoidable/inedible". According to Parfitt et al. (2010) the differentiation between the definitions related to food loss and waste were created precisely to characterize food in edible consumption conditions that did not reach the consumption phase in supermarkets, or even those which for one reason or other, ended up in the trash. Lebersorger \& Schneider (2011) give an overview of different options for classifying food waste by discussing its applications. This distinction among definitions is very clear in Figure 1, where food loss and waste are highlighted in a food supply chain (FSC) diagram.

The main reasons responsible for the waste of food are due to marketing actions aimed at consumption for stock, economic contingencies, regulatory measures for the control of validity (Gustavsson et al., 2011), in addition to inadequate management of inventory, food is not used in time and too much food is cooked, prepared or served (Parfitt et al., 2010).

\section{Materials and methods}

For the elaboration of this study, the following steps were established (Cooper, 1989): choice of the research question; definition of criteria for inclusion and exclusion of studies; sample selection (Figure 2); inclusion of selected studies in a table format constructed in an electronic spreadsheet; analysis and discussion of the results evaluating the main aspects. In addition, the bibliometric method was performed in the study.

The research of the study material was performed on the following bases: Web of Science and Google Scholar using the descriptors: food waste, food service, catering, hospitality and sustainability. The filters used in all crosses were: year of publication from 2009 to 2019, some criteria such as deleting repeated articles, aligning with the title, aligning with the abstract, availability, and general alignment. Figure 2 shows the procedures for refining the sample obtained in the two bases, considering the sample selection stage. 67 articles were selected in the Web of Science database using the descriptors above and 71 in Google Scholar, totaling 138 articles.

The analysis of large amounts of academic documents in a literature can be aided using some computational tools such as bibliometric software, facilitating the researcher's task, which seeks through reading, setting the theme scenario related to your 


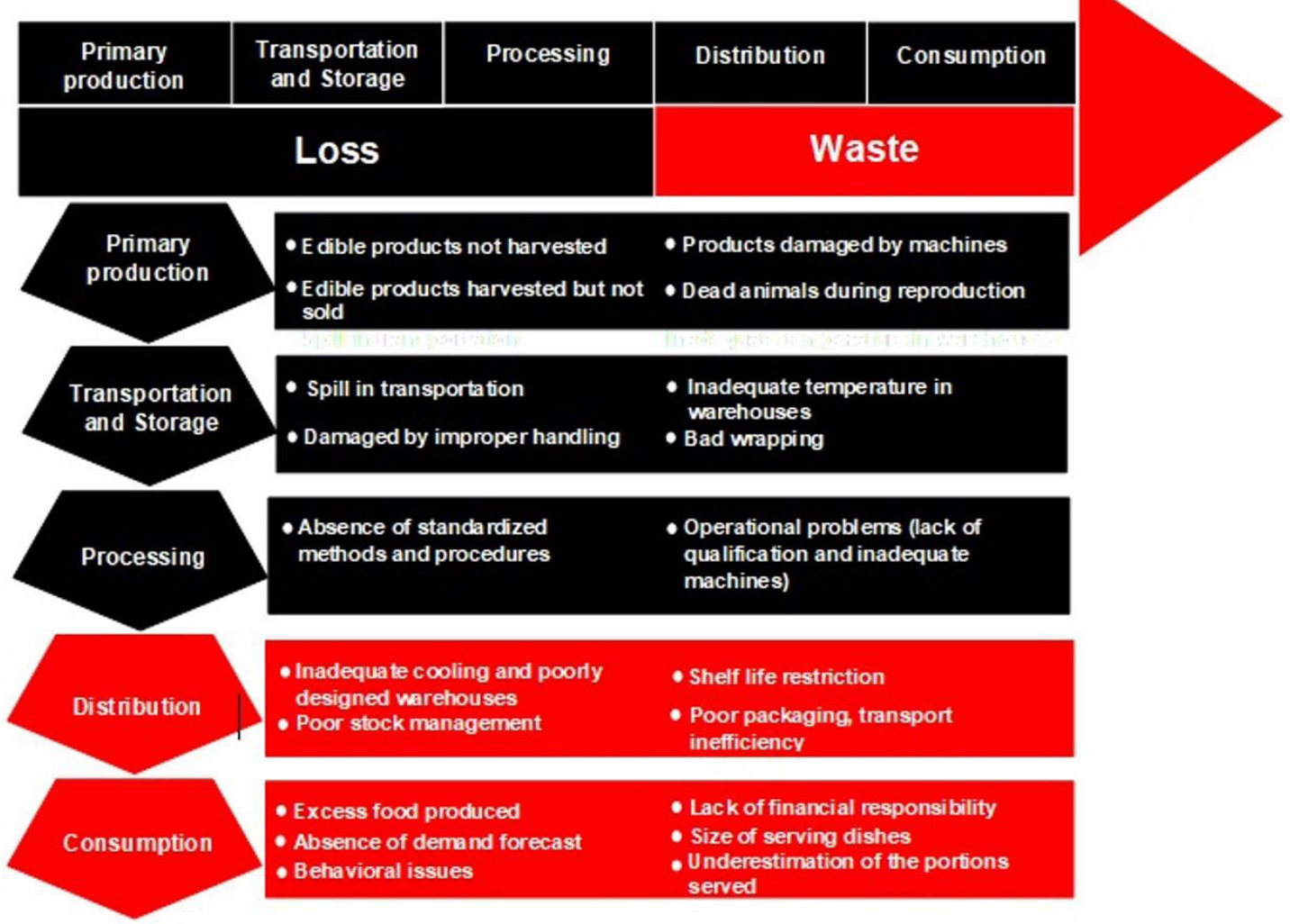

Figure 1. Correspondence and causes associated with waste and food loss.

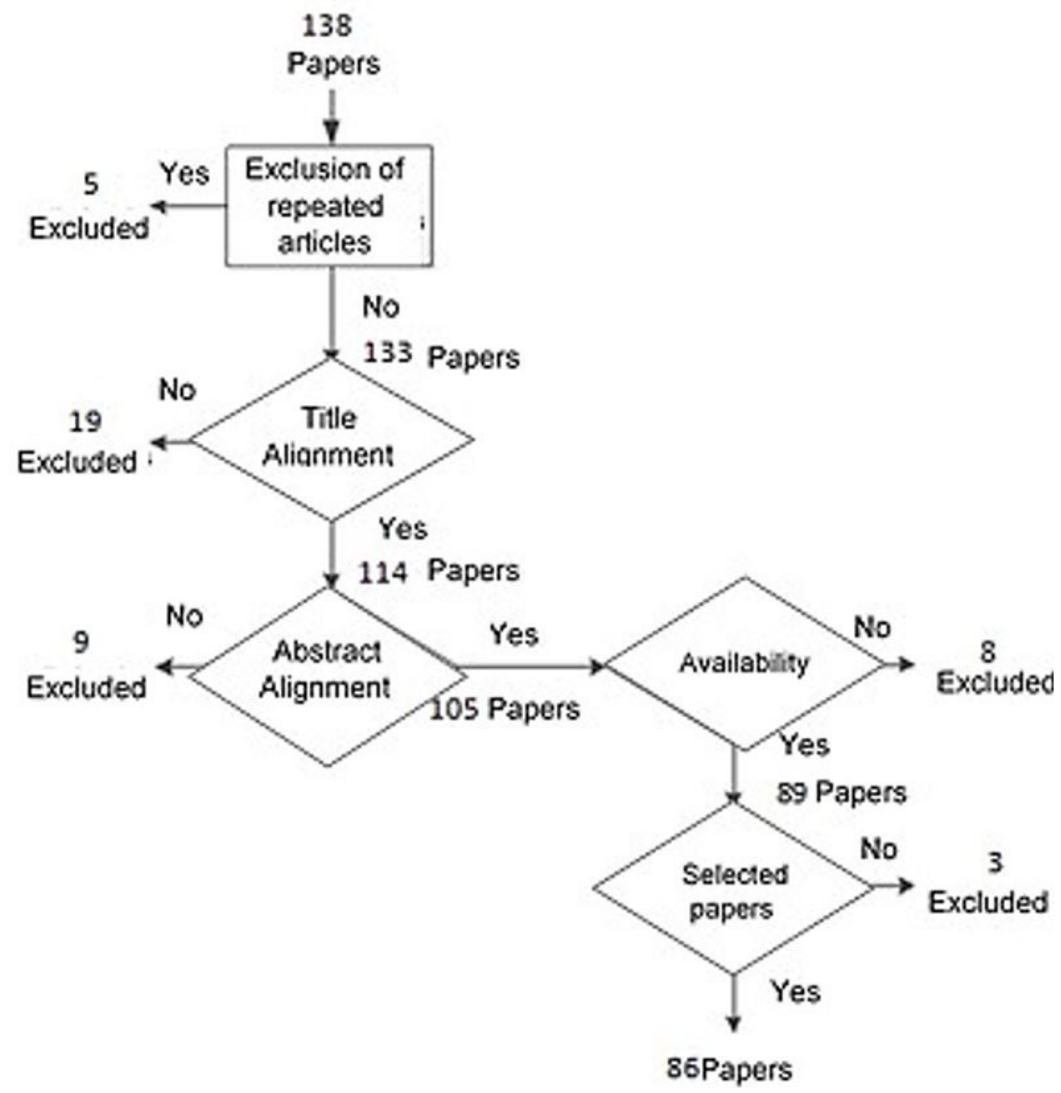

Figure 2. Procedures for selecting papers. 
search. Bibliometric software is a tool capable of measuring and facilitating the analysis of information stored using algorithms and statistical tools. According to Oliveira (1984) although its use entails some difficulties, many useful informations can be used to the transmission of ideas and tendencies of a scientific issue.

In this work, a succinct bibliometric analysis of the data obtained through the base "Web of Science" and "software Vosviewer" was performed highlighting some basic characteristics of academic research in food service.

\section{Results and discussion}

\subsection{Bibliometric analysis}

Figure 3 shows the number of publications from 2009 to 2019 focused on the study of food waste in food services.

Although the number of publications per year is not very representative, it can be noted in Figure 3, a gradual increase in publications showing a greater interest in research focused on the problem of negative impacts on the environment resulting from the food waste in food services. It is possible to note that the number of papers doubled from 2017. Figure 4 shows the countries with the highest number of publications on food waste in food services between 2009 and 2019.

In relation to the ranking of the five countries with the highest number of publications these stand out: Italy, China, India, Portugal, Germany, getting Brazil in the eighth position which demonstrates a significant global position, in the research focused on waste. In Figure 4 it is possible to notice in the infographic by the variation of the colors of the countries, which indicates a recent developing research on the subject, leaving Sweden and Germany in a prominent position. Figure 5 shows the academic journals with the highest number of publications addressing the theme food waste in food services between 2009-2019.

Evaluating the journals with the highest number of publications per year, those in a prominent position are Waste Management, Journal of Cleaner Production, Appetite and British Food Journal. In relation to the current research, it is possible to notice the gradient of colors present in the graph that the journal Cleaner Production is in the first position followed by Resources Conservation and Recycling.

\subsection{Sustainability in food services and waste generation}

The use of good practices aimed at reducing the environmental impacts within the food services is considered a promoter of sustainability, either through the rational use of resources and raw materials or even of technologies and procedures that enable the mitigation of waste. Martinelli (2011) cite that sustainability within the food services can be achieved by adopting decisions that prioritizes the use, for example, of traceable food from agroecological farming, as well as the training of employees directly and indirectly involved with the production of meals, in addition to the implementation of environmental protection policies.

The inadequate of disposal of products and packaging generated by the food services through the adherence of efficient policies for solid waste management (Abreu \& Pinto, 2009) and the use of non-biodegradable chemicals associated with waste of water and energy (Proença et al., 2005) that compromise the environment, should be considered measures to prevent waste.

In 2008, the U.S. food service industry earned approximately 558 billion dollars, occupying the position of the largest private sector employer, according to the National Restaurant Association NRA (Chancey, 2008). About $42 \%$ of U.S. consumer spending on food is carried out in food/restaurant establishments (U.S. Bureau of Labor Statistics, 2010). In Brazil, many commercial and institutional food services have focused on making their activities more sustainable (Hu et al., 2010).

Between 2003 and 2007 there was a significant growth in the collective meal market in Brazil, representing an increase of more than $100 \%$, making the collective food sector very important for the national economy (Martins et al., 2016). The nature of the operations carried out in food services is intrinsically related to sustainability, because they demand a large consumption of basic utilities such as water and energy for the preparation of meals and conservation in air-conditioned or even chilled environments and are responsible for generating a range of

\section{Number of publications per year}

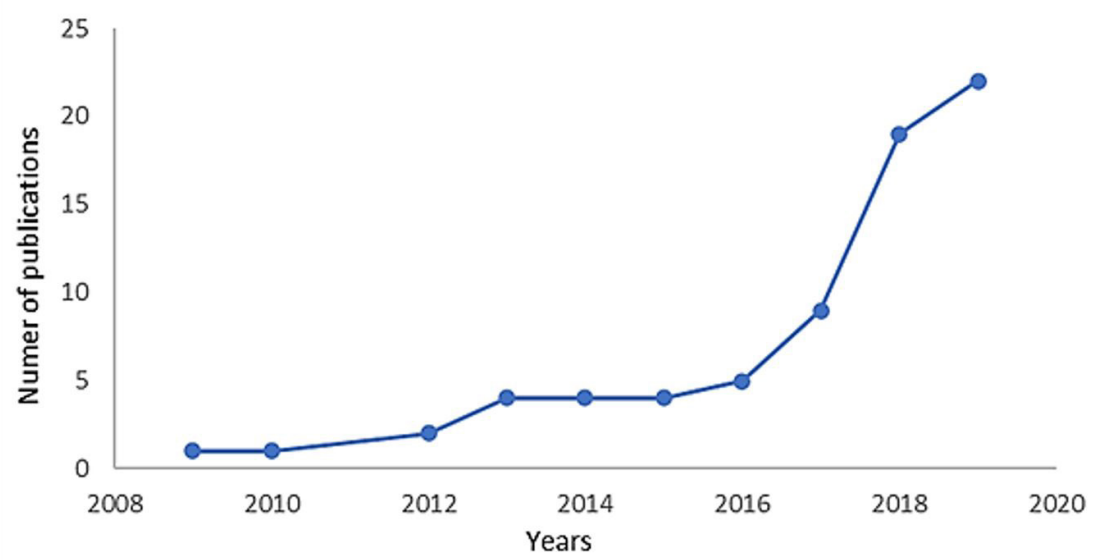

Figure 3. Number of publications in (food waste in food services) between 2009 and 2019. 


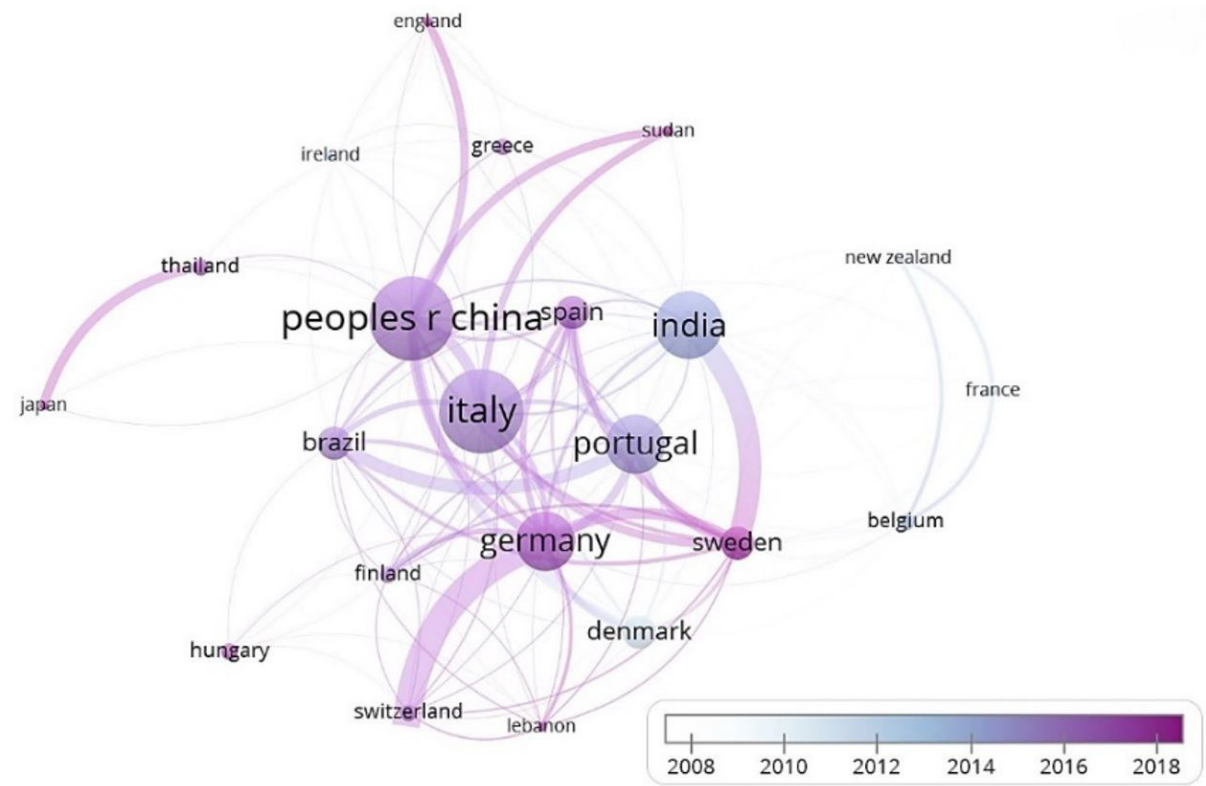

Figure 4. Publications by countries (food waste in food services) between 2009-2019.

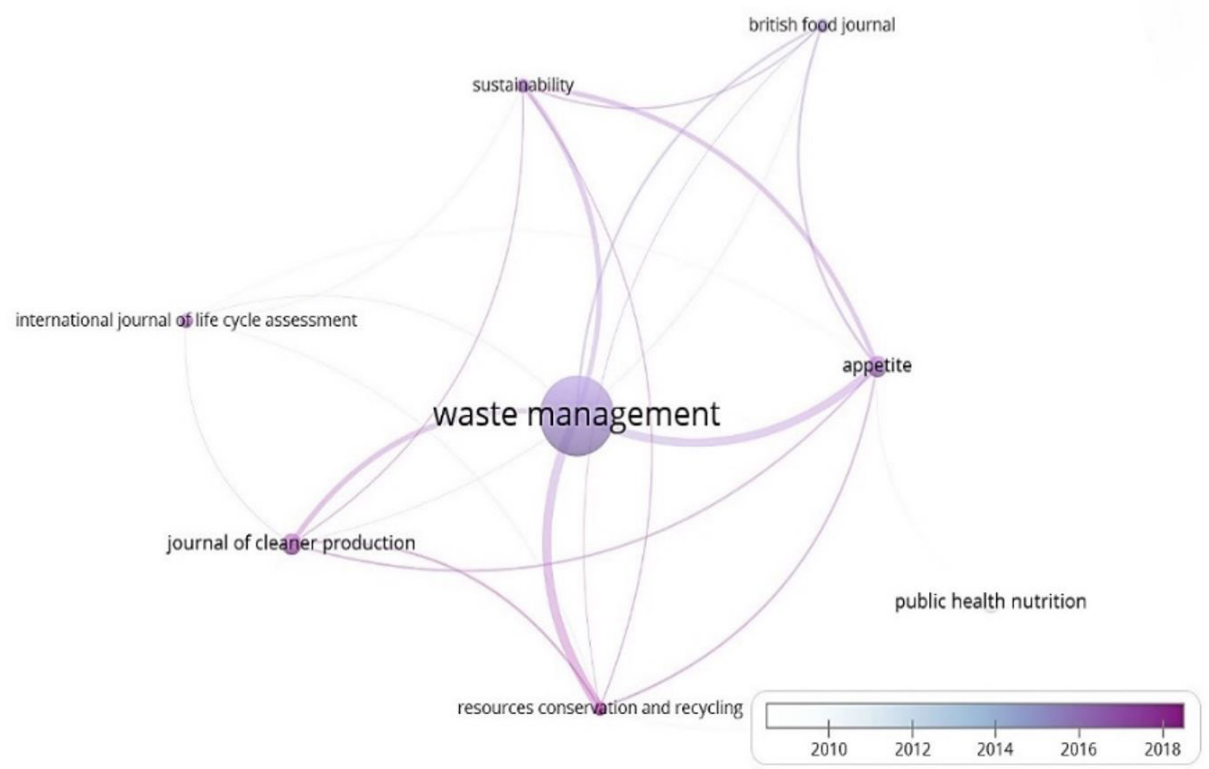

Figure 5. Publications by journals (food waste food service) between 2009-2019.

waste. In view of this fact, the improvement of environmental aspects becomes a challenge for managers of the food sector, facing other demands such as controlling costs, managing the supply chain and, meeting the demands and needs of customers (Abreu \& Pinto, 2009).

Studies developed by Alamar et al. (2018) related to the minimization of food waste indicate that there is a lack of qualified human capital, and that the existing networks of researchers that focus on the loss and waste of food are not fully connected. The authors Schanes et al. (2018) consider it necessary to change the paradigm in research for a multidisciplinary and collaborative focus that gathers several areas of knowledge as biology, engineering, statistics and behavioral.

\subsection{Environmental impacts resulting from the production of food and meals in food services}

Water consumption, energy and land use

The preparation or production of meals involves a series of steps and activities such as receiving/wrapping, manipulation/ preparation and distribution among others that require the use of a wide range of resources and raw materials necessary. Water is used in all stages of cleaning and hygiene, not only of the food, but also of the physical structure, machinery, equipment and utensils, besides being used in cooking. (Strasburg \& Jahno, 2017) cities that the use of electric energy is necessary for the refrigeration and freezing of food, as well as for the operation 
of electrical equipment and maintenance in the distribution in hot or cold storage. In this way, it is necessary to understand the consumption and use of these resources in order to control them.

In the United States, there is a consumption of approximately $2 \%$ electrical energy regarded to the waste food generation per year, this consumption can be considered substantial when compared to some programs for conservation and energy production. This estimate is the result of a study conducted by Cuéllar \& Webber (2010), the authors still affirm that for a more accurate analysis, it is necessary to update the national estimate for the waste of food and energy necessary for its production.

The consumption of electric energy per meal was measured in a study conducted by Barthichoto et al. (2013) in 32 restaurants in the city of São Paulo, observing a variation in the average consumption of $0.2 \mathrm{~kW} / \mathrm{h}$ to $1.3 \mathrm{~kW} / \mathrm{h}$. The authors also state that only $37.5 \%(\mathrm{n}=12)$ of the 32 establishments have been performing a procedure for measuring electricity consumption (Martins, 2015).

The Flammini et al. (2013) estimated that the total global consumption of water used to produce food lost in its total production chain is equivalent to three times the size of Lake Geneva, demanding an area for planting of approximately 1.4 billion hectares. Practically all stages intended for the preparation and production of meals in the food service use resources such as water and electricity, so that these utilities are considered indispensable to this activity (Strasburg \& Jahno, 2017).

The level of drinking water consumption for the defrosting of beef in running water in the food service was measured by Martinelli et al. (2012) and the results revealed a consumption of approximately $8.340 \mathrm{~L}$ of water to defrost $109.5 \mathrm{~kg}$ of beef. The average daily use was approximately $1.668 \mathrm{~L}$ of water for $21.9 \mathrm{~kg}$ of beef and approximately $76.2 \mathrm{~L}$ of water $/ \mathrm{kg}$ of meat. The average water flow was $5.2 \mathrm{~L} / \mathrm{min}$, reaching $14.8 \mathrm{~L} / \mathrm{min}$.

Evaluating the water consumption demanded by the activities in the food service, results of a study conducted by Martins (2015) in 12 commercial restaurants in Paraná indicated that the average water consumption was $38 \mathrm{~m}^{3} / \mathrm{month}$, or about $11 \mathrm{~L} / \mathrm{meal}$. Also, studies conducted by Pierre et al. (2013) in an restaurant of the Federal Institute of Ouro Preto-Minas Gerais-MG, for 10 days to the production of 929 meals/day evaluated a consumption of $25 \mathrm{~L}$ of water per meal. Otherwise, a result of studies conducted by Lustosa (2011) in a commercial restaurant in Rio de Janeiro to produce 1500 meals/day for three months indicated a water consumption of approximately $26 \mathrm{~L} /$ meal.

\section{Solid waste production and adoption of environmental practices}

Solid waste management in food service represents an important point in the meal production process. Less than $3 \%$ of the food wasted in the United States was recycled or used for composting in the year 2010 (Buzby et al., 2014). This type of residue corresponds to about $21 \%$ of the municipal landfill components in the United States (Environmental Protection Agency, 2014).

Landfills account for about $34 \%$ of all methane emissions related to food consumption and disposal in the United States
(Environmental Protection Agency, 2011). In addition to methane, landfills produce leachate, a mixture of liquid residues by-products resulting from the degradation of organic matter along with rainwater, which may contaminate groundwater, or even water tables, if the landfill sites are not adequately prepared.

Among the residues generated by the activities present in the Food Service, the cooking oil is considered as one of the major polluters of soil and groundwater. Ferreira \& Santos (2016) cite that one liter of oil can contaminate about one million liters of water. Besides, when improperly disposed of oil, it is difficult to treat the sewage system and may also contaminate rivers, lakes and the ocean (Lopes \& Fonseca, 2013).

In the case of Brazil, it ranks as the largest country in Latin America that generates Solid Urban Waste (MSW), however, only $58.7 \%$ of MSW collected in 2015 were properly disposed of in landfills, the reactor about $41 \%$ were improperly disposed of, usually in open dumps or controlled landfills. This amount represents about 29,973,482t, of this total, around 55\% represents organic waste, i.e. about 16,485,415t (Associação Brasileira de Empresas de Limpeza Pública e Resíduos Especiais, 2017). Figure 6 shows the main environmental impacts resulting from food production and meals in food service.

Studies conducted in an university restaurant of the Federal University of Rio Grande do Sul (UFRGS) by Strasburg \& Pereira (2014), evaluating the applicability of the Survey of Environmental Aspects and Impacts (LAIA) for the activities developed in the restaurant, revealed that five of the thirteen groups of environmental aspects are not applicable and about $44 \%$ of the 54 items evaluated in the LAIA are also not applicable to the reality of the restaurant.

In a restricted manner, some authors emphasize that the standardization actions proposed by the quality management programs help in saving time and money (Alonso-Almeida et al., 2012). There is currently a progressive increase of Quality System Certificates in the industry in general because there is a concern on the part of companies to improve their processes, products and services to improve their image against the competition (Rubio-Andrada et al., 2011).

Studies focused on the improvement of the environment mostly are directed to the industrial sector and large companies. A survey conducted in the region of Madrid (Spain) in the year 2010 by Llach et al. (2013) where 374 questionnaires were applied to managers of small companies in the food and beverage segment, in order to observe the adoption of measures more compromised with the environment. Their research showed that the segment of restaurants and collective food has received little attention in relation to the adoption of measures more committed to the environmental issues.

\subsection{Factors responsible for the generation of waste from food services}

The performance of a careful analysis considering particularities of behavior and attitude of consumers facilitates the understanding of the subjective variables that relate to the act of waste. Also evaluating questions of a technological nature and 


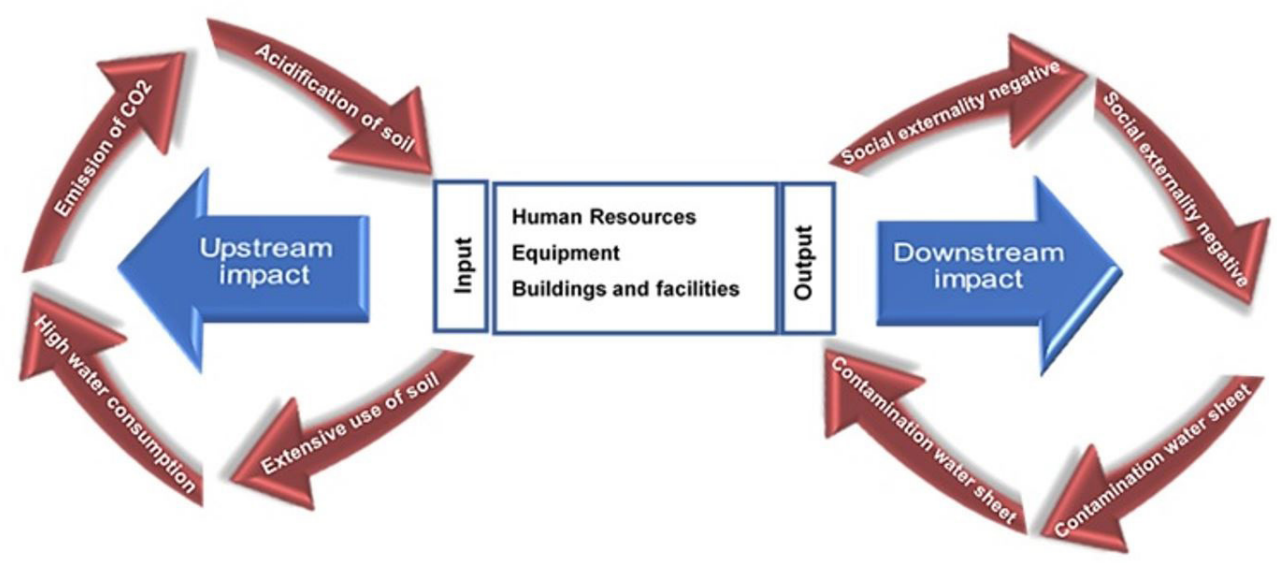

Figure 6. Upstream and downstream impacts resulting from food production in food service.

methods employed is necessary, since, much of the root causes of waste in the food service derive from these aspects. To make the activities of food services more sustainable as per Proença (2000) it is necessary to carefully observe all the tasks performed in the production of the meal as: planning of menus, acquisition of genres, storage, pre-preparation, preparation, distribution.

\subsection{From consumers}

Although it is in the interest of many individuals and institutions to reduce the amount of food they waste, for financial and environmental reasons, Graham-Rowe et al. (2014) affirms that reducing food waste at the consumer level in an institutional environment such as a university cafeteria is usually very costly from the point of view of effort and mental energy employed, this is because diners do not receive direct benefits by reducing waste, implying in uncompromising behavior, which may favor waste.

In addition, most students living on the university campus are benefited by financial aid for food, as well as part of the cost of paying diners is subsidized by public universities. In other situations, the costs of many students' meals are paid by their parents, which also reduces the financial responsibility of diners. Within this perspective, Rand \& Nowak (2013) affirm that individual efforts to reduce waste are perceived or classified as cooperative behaviors, where an individual assumes a cost for the benefit of the other.

Most consumers are unaware of the food they waste beyond witnessing waste as an inevitable fact, in this way they believe that the act of wasting is common and they do it (Lagorio et al., 2018). The increase in the number of conscious consumers about food waste is something that has been widely discussed among researchers (Pinto et al., 2018).

Studies conducted by Quested et al. (2013) cities that it is necessary to adopt policies aimed at consumer awareness, modifying the behavior of food waste, in addition to arousing consumer responsibility and commitment to this issue. However, other studies have assessed that certain interventions aimed at raising awareness do not sufficiently reduce food waste (Watson \& Meah, 2013), because there are other more complex causes associated with behavioral aspects that make the process of awareness ineffective in practice. Evans (2012) proposes that efforts can be directed to material aspects related to food packaging, such as the size and shape of the packaging.

The environmental impacts resulting from dietary choices depend on the nature of the food item (Garnett, 2011). Meat and other animal products tend to have higher environmental impacts because of their higher trophic level and related to their inefficiency of production (Clay, 2004).

The lack of clear information about the environmental impacts that each food produces makes it difficult to consume items less compromised with the environment, limiting individuals to consider only factors such as price, caloric value etc. (Marreiros \& Ness, 2009). As such, demand initiatives aimed at shifting diets to more sustainable choices have been repeatedly identified as crucial to addressing food security and environmental impacts (Garnett, 2011).

Another aspect associated with the generation of waste is related to the size of the dishes. Studies conducted by Kallbekken \& Sælen (2013) in a hotel located in Norway, Nordic Choice Hotels, have concluded that it is possible to considerably reduce the waste index. The study consisted in the deliberate reduction of the size of the dishes so that the diners/customers ate in a fractionated manner, that is, to put only the quantity needed or lower than it and repeat adding another portion without excesses. This small intervention reduced food waste by around $20 \%$.

This experiment fits exactly with observations made by Wansink \& Van Ittersum (2013) that the size of the dishes, bowls and spoons skew the quantity or volume of food placed in these containers. That's because, usually people overestimate the amount of food they're going to eat and underestimate the amount of food that fits in larger containers like a big dish for example. The study developed by the authors above evaluated the behavior of 209 participants in a health conference, where those who had chosen larger plates wasted more than those who had chosen dishes with smaller size.

The same study evaluated in a Chinese buffet that worked with large dishes, the result was that the diners served about $52 \%$ more; they ate approximately $45 \%$ more and wasted $135 \%$ more. Finally, the authors concluded that the diners/customers 
established the internal diameter of the plates as the consumption norm, this being the level of filling to be used, justifying the increase of food when the size of the dishes increases. This aspect relates to the Delboeuf illusion that distorts the perception of the amount of food that can be put on the dishes as its size increases. Table 1 presents some of the main reasons for waste, having the diners as reference.

\subsection{Related to lack of a proper method and procedures}

The lack of forecasts of demands and inaccuracy in the definition of menus, associated with inadequate operating methods and procedures, are considered potential factors to generate waste. In relation to the elaboration of the menus should be taken into consideration some aspects such as: calculations of the quantity per capita of portions, correction factor (HR) and cooking yield (Lagorio et al., 2018). It is important to note that these data must be contained in the datasheet of each preparation (Ornelas, 2006).

Although selecting what to cook is important in terms of food waste minimization strategy (Painter et al., 2016) this action may not be very feasible, for example, for a commercial restaurant located in a hotel, where the variety of served dishes is quite wide. However, establishing as a method the selection and identification of the types of dishes that tend to generate less waste during their preparation and try to serve them preferably, or even, integrate them into menus that potential customers can choose for events, will certainly enable a decrease in waste rates.

In a study conducted by Pirani \& Arafat (2016) analyzing the management of food residues in the hospitality sector in the city of Abu Dhabi in the UAE, the authors observed that the factors that most contribute to the generation of food residues are related to the preparation procedures, the service time, planning instruments and the type of food served, that is, the variation of the menu, besides the assertive prediction of the number of diners.

The non-use of planning instruments such as a technical data sheet brings implications to the steps of manipulation and preparation, because, the non-use of the technical data sheet will not allow the employee responsible for this stage to perform the controls related to the menu planning. Akutsu et al. (2005) affirms that the technical data sheet is a useful tool to assist the planning and serves as a form of control for some variables such as: correction factor, number of portions, cooking factor and yield. The previous knowledge of this information is fundamental for the identification of the quantity of foods to be produced, avoiding waste, besides allowing a better financial control related to the items used. Table 2 shows some reasons for the generation of waste associated with the lack of appropriate methods, planning and procedures.

Not diversifying the cutting patterns, but also not varying the types of vegetables and ingredients that make up the salads contributes directly to the increase of waste. In a study conducted by Soares et al. (2011) in eight commercial restaurant of a large company it is evident that the cost of the waste of clean leftovers, that is, prepared and unserved food is quite significant. Conversely, Proença et al. (2005) affirms that the variety of vegetables and ingredients that make up salads can contribute to sharpen the interest in consumption and reduce waste.

\subsection{Main focus on research in the last 10 years}

Figure 7 presents a map of authors approaching aspects such as Underlying factors, Sustainability and use of Methodologies and tools for analysis, control and measurement of food waste.

Through the authors' map it is easy to identify what is the principal focus given to the work undertaken considering the theme of food waste in commercial and institutional food services. It is possible to observe in the authors' map in a more specific way (Underlying factors) that most authors are involved with research that aim to analyze behavioral aspects, of choice of individuals, composition and acceptance of the menu, as well as for planning and preparation of meals, usually not assessing the interaction of the influence of these aspects in the generation of waste. It is possible to highlight the existence of a gap in research aimed at understanding the root causes of the

Table 1. Underlying reasons for food waste in food service.

\begin{tabular}{|c|c|c|c|}
\hline Source & Methodology & Reasons to waste & $\begin{array}{c}\text { Reduction and preservation } \\
\text { measures }\end{array}$ \\
\hline Graham-Rowe et al. (2014) & $\begin{array}{c}\text { Qualitative data analysis, } \\
\text { application of a semi-structured } \\
\text { questionnaire }\end{array}$ & Lack of financial responsibility & $\begin{array}{c}\text { Adoption of campaigns and actions } \\
\text { aimed at reducing waste }\end{array}$ \\
\hline WRAP (2016) & $\begin{array}{l}\text { Online interview with } 5414 \\
\text { respondents }\end{array}$ & $\begin{array}{c}\text { Lifestyle-related convenience, } \\
\text { Financial irresponsibility. }\end{array}$ & $\begin{array}{l}\text { Public policies aimed at the use/ } \\
\text { consumption of food }\end{array}$ \\
\hline Grandhi \& Appaiah Singh (2016) & Multiple Discriminant Analysis & $\begin{array}{l}\text { Absence of methods to classify, } \\
\text { food, Lack of food consciousness. }\end{array}$ & 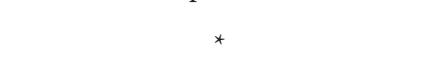 \\
\hline Parizeau et al. (2015) & $\begin{array}{c}\text { Field search in } 68 \text { commercial } \\
\text { restaurants }\end{array}$ & $\begin{array}{l}\text { Lifestyle-related convenience, } \\
\text { Beliefs, Family Lifestyle. }\end{array}$ & * \\
\hline Strasburg \& Jahno (2017) & Systematic review of the literature & Behavioral issues. & Breaking of Paradigms \\
\hline Kallbekken \& Sælen (2013) & $\begin{array}{l}\text { Field search in } 52 \text { commercial } \\
\text { restaurants }\end{array}$ & Size of dishes used to serve & $\begin{array}{l}\text { Reduction of the size of the dishes; } \\
\text { Suggestions of social nature }\end{array}$ \\
\hline Reinders et al., (2017) & $\begin{array}{c}\text { Case study in } 04 \text { commercial } \\
\text { restaurants }\end{array}$ & $\begin{array}{c}\text { Size of dishes used to serve; } \\
\text { Underestimation of the portions } \\
\text { served }\end{array}$ & Reducing the size of the dishes \\
\hline
\end{tabular}

Note: ${ }^{*}$ empty. 
Table 2. Generation of waste associated with lack of methods, planning and appropriate procedures.

\begin{tabular}{|c|c|c|c|}
\hline Method & Planning and control & Procedure and technique & Infrastructure technology \\
\hline $\begin{array}{l}\text { - Inappropriate methods of } \\
\text { manipulation and preparation }\end{array}$ & - No demand forecasts & $\begin{array}{l}\text { - No adoption of quality tools and } \\
\text { techniques }\end{array}$ & $\begin{array}{l}\text { - Unsuitable equipment for } \\
\text { unloading and handling }\end{array}$ \\
\hline - Adoption of inappropriate menus & - Inaccuracy of demand forecasts & $\begin{array}{l}\text { - Lack of technical knowledge for } \\
\text { conditioning }\end{array}$ & - No cooling chamber \\
\hline $\begin{array}{l}\text { Absence of adherence to waste } \\
\text { management programs }\end{array}$ & - No technical data Sheet & $\begin{array}{l}\text { - Inefficient receival and checking } \\
\text { control of raw material }\end{array}$ & - Inappropriate Layout \\
\hline \multirow[t]{3}{*}{$\begin{array}{l}\text { Inconsistent and outdated } \\
\text { purchasing policy }\end{array}$} & $\begin{array}{l}\text { - Non - standardized cooking and } \\
\text { correction factors }\end{array}$ & & \\
\hline & $\begin{array}{l}- \text { No cooking and correction } \\
\text { factors. }\end{array}$ & & \\
\hline & - Inefficient inventory management & & \\
\hline
\end{tabular}

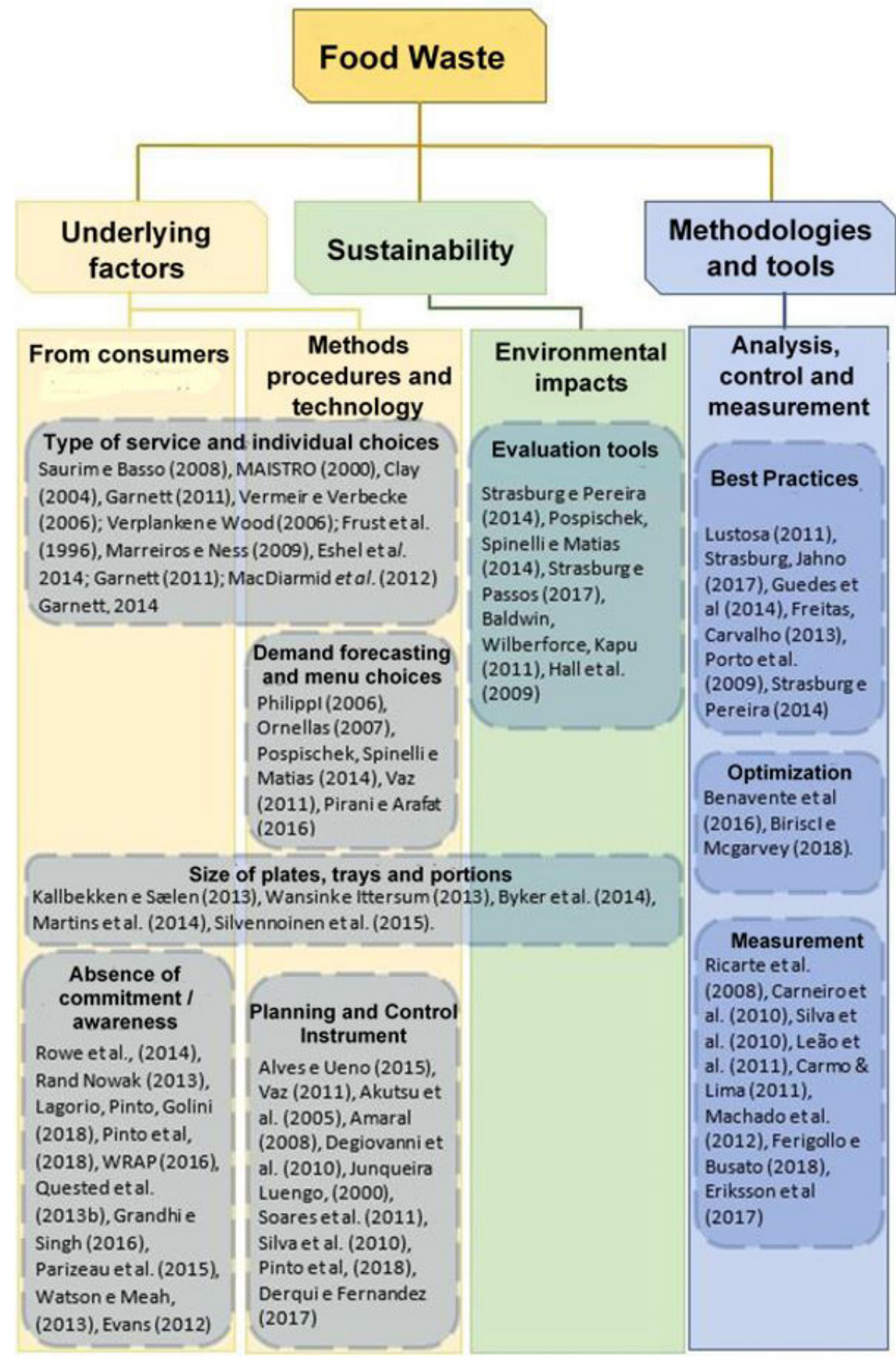

Figure 7. Authors' map. 
drivers and generators of food waste in food service, as well as the reduced presence of authors interested in evaluating how the subjective aspects related to the practice of waste can be treated within a multivariate perspective, by the use of specific tools of engineering and statistics such as Fuzzy Logic, Analysis by Structural Equations, System Dynamics, etc.

The use of these tools enables the assessment of causal relationships and subjective aspects of waste generation, bringing a new perspective to research in the Food Service sector, contributing to the breaking of the current paradigm, where the pronounced focus is waste itself and not the root causes.

When the focus is analysis and control of waste, most of the authors only limit themselves to quantifying the wastes in order to compare them with values recommended by the literature. It is also possible to highlight that when it comes to the generation of food waste in Food Service, there are very few works that approach the production system, considering areas as storage, handling, preparation and service by a Cleaner Production approach, as well as specific tools of the Production Engineering e.g: Statistical Process Control -SPC, Failure Mode and Effects Analysis - FMEA, Mapofluxogram, etc. The use of the aforementioned tools in new research, considering the tasks analysis involved in all of the areas above cited can directly contribute to the improvement of the efficiency of the analyzed productive system, consequently bringing a gain in its environmental efficiency.

Regarding environmental impacts, the use and consumption of basic water and energy inputs, it is possible to observe that although the results of the studies carried out indicate an exaggerated use of water for cooking, cleaning and defrosting, this research does not emphasize the development of new methods and technique for more efficient defrosting. It is also noted that the research does not propose the use of water reuse systems as a way to minimize their demand. Otherwise, it is also perceived in the map of authors that there is a reduction in the number of authors with research aimed at evaluating the real negative impacts caused to the environment by the activities that occurred in food services.

The most studies of Life-cycle Assessment focused on the production chain not specifically considering the activities carried out by Food Service. Some studies were found that evaluated the water and carbon footprint for the composition of ecological menus, however, the LCA assessments need to be more comprehensive in the Food Service activity. Besides that, the use of mathematical models and computational algorithms can contribute to the prediction of more sustainable scenarios when dealing with food waste in Food Service, but there is a gap in research, considering algorithms and mathematical models to make more assertive predictions of food quantities to be produced taking into consideration the variety of the menu and the ecological footprint of the food, mainly related to meat consumption.

Although there are a concern and greater control in the monitoring of water used, few studies address the issue of food waste considering the energy used in processing, cooling/ freezing, and heating activities. This situation is even worse when we consider research focused on the use of biomass conversion techniques to produce electricity, such as the production of biogas from food waste in biodigesters. It should be noted that there is a real need for further research on energy efficiency in the Food Service sector to reduce its demand for electricity from non-renewable matrices.

Finally, the authors' map emphasizes the need to broaden the number of research and authors that assess the problems of food waste in food services in further perspective, that is, beyond the boundaries of the measurement of waste. The research that considers the development and enhancement of techniques and tools to mitigate waste at its origin, that is, in the light of the understanding of new approaches that consider the complexity hidden in the causes or reasons for the generation of food waste are essential for a new positioning of the Food Services toward the control of the environmental impacts resulting from its activities.

\section{Conclusion}

This work identified different aspects and factors responsible for the generation of food waste in commercial and institutional Food Service. It is possible, through reading, to clearly observe that the phenomenon of food wastage can be seen as a process whose origin is multifaceted, that is, it presents multiple root causes. However, the vast majority of publications are limited only to the measurement of waste indexes such as: waste-ingestion, clean leftovers, and some authors evaluate the waste related to the manipulation and pre-preparation phase usually related to the lack of monitoring and non-standardization of the correction factor. Another part of the publications assesses aspects related to the management of residues derived from waste.

Although there is a growth in the market of food services, implying a possible increase in the impacts resulting from this activity, it is possible to observe a greater commitment of the food service with the reduction of food waste, and also regarding the adoption of environmental practices such as waste management policies. However, it is worth stating that this commitment is always tied to the reduction of financial impacts within a "tradeoff" perspective, where compensations do not always favor the reduction of environmental impacts.

The results show also that food waste is usually attributed to diners for reasons such as financial disengagement or even associated with cooperative behaviors, where an individual assumes the cost for the waste of others. The lack of food awareness is seen by some researchers as the main reason for waste by diners, besides the lack of information about the environmental impacts related to each type of food, making them unable to choose a more sustainable menu.

About $16,485,415$ t of organic waste will end up each year in landfills, controlled landfills, and dumps in Brazil, of this amount around $17 \%$ will be sent to dumps where it will be mixed with other types of solid waste and will decompose, contributing to the proliferation of vectors harmful to health, besides contaminating the soil and emitting large amounts of CO2 into the atmosphere (Associação Brasileira de Empresas de Limpeza Pública e Resíduos Especiais, 2017). 
In Brazil, FAO states that the volume of wasted food reaches a volume of 40000 tons/day, generating enormous economic losses to the country (Food and Agriculture Organization, 2013). The Brazilian Association of Collective Meal Companies (ABERC), foresaw for the year 2018 a supply of approximately 13 million meals/day, and an income of approximately $\mathrm{R} \$ 19.3$ billion (Associação Brasileira das Empresas de Refeições Coletivas, 2018). Considering that the acceptable percentages described by the literature of waste/leftover food for a healthy collective may vary between 4 and 7, or be less than 10\% (Vaz, 2011), it can be considered for the year 2019 waste to be more than 1 million meals/day throughout in Brazil, and about 25,000m3 of water considering literature data with 251 of water per meal.

The results found in this work highlight the main factors associated with the practice of waste in food service. These factors should be considered as those of greater criticality, requiring greater attention from managers and supervisors of the production units. Considering a medium and long-term scenario, in addition to causing a series of economic losses, food waste directly implies a series of damage to the environment that can compromise the food security of future generations.

Within this perspective, this research highlights the lack of scientific work within Food Science that takes into account the problem of food waste from a broader perspective, that is, beyond the limits only of the measurement of wasted quantities. The results of this research indicate the need for the development and improvement of new methods, techniques and tools that can mitigate waste in its origin, taking into account the totality of its complexity.

This work emphasizes and suggests for future research the use of tools to evaluate causal relationships and interdependence between variables present in the issue of waste such as Fuzzy Logic, Analysis by Structural Equations, System dynamics Etc, in addition tools and methods focused on the origin of waste generation, such as Mass Flow Analysis-AFM and Cleaner Production concepts ". This suggestion, aims to open new frontiers related to studies focused on the generation of food waste in the Food Service, enabling a more accurate and assertive analysis of the problem of food waste.

\section{Acknowledgements}

The authors are grateful to the FAPESB - Research Support Foundation of the State of Bahia for the financial support under grant BOL0422 / 2018.

\section{References}

Abreu, S. M. G. N., \& Pinto, A. M. S. (2009). Food and nutrition management: a way of doing. Brasília: Metha.

Akutsu, R. C., Botelho, R. A., Camargo, E. B., Sávio, K. E. O., \& Araújo, W. C. (2005). The preparation fact sheet as a quality tool in meal production. Nutrition Magazine, 18(2), 277-279.

Alamar, M. C., Falagán, N., Aktas, E., \& Terry, L. A. (2018). Minimising food waste: a call formultidisciplinary research. Science Food Agricult, 98(1), 8-11. http://dx.doi.org/10.1002/jsfa.8708.
Alonso-Almeida, M. M., Rodríguez-Antón, J. M., \& Rubio-Andrada, L. (2012). Reasons for implementing certified quality systems and impact on performance: an analysis of the hotel industry. Service Industries Journal, 32(6), 919-936. http://dx.doi.org/10.1080/0264 2069.2010.545886.

Associação Brasileira das Empresas de Refeições Coletivas - ABERC. (2018). Mercado Real. Retrieved from: http://www.aberc.com.br/ mercadoreal.asp?IDMenu=21.

Associação Brasileira de Empresas de Limpeza Pública e Resíduos Especiais - ABRELP. (2017). Panorama of solid waste in Brazil 2016. Retrieved from www.abrelpe.org.br/pdfs/panorama/panorama_ abrelpe_2017.pdf

Azapagic, A. (2003). Systems approach to corporate sustainability: A general management framework. Process Safety and Environmental Protection, 81(5), 303-316. http://dx.doi.org/10.1205/095758203770224342.

Baldwin, C., Wilberforce, N., \& Kapur, A. (2011). Restaurant and food service life cycle assessment and development of a sustainability standard. The International Journal of Life Cycle Assessment, 1(1), 40-49. http://dx.doi.org/10.1007/s11367-010-0234-x.

Barthichoto, M., Matias, A. C. G., Spinelli, M. G. N., \& Abreu, E. S. (2013). Environmental responsibility: profile of sustainability practices developed in meal-producing units in the Higienópolis neighborhood, São Paulo. Qualitas Electronic Magazine, 14, 1-12.

Buzby, J. C., \& Hodan, F. W., \& Hyman, J. (2014). EIB-121: the estimated amount, value, and and calories of postharvest food losses at the retail and consumer levels in the United States. Washington: U.S. Department of Agriculture, Economic Research Service. Retrieved from www. ers.usda.gov/webdocs/publications/43833/43680_eib121.pdf

Buzby, J. C., \& Hyman, J. (2012). Total and per capita value of food loss in the United States. Food Policy, 37(5), 561-570. http://dx.doi. org/10.1016/j.foodpol.2012.06.002.

Chancey, B. (2008, December 13). NRA 2008 forecast coverage: predicts 2008 to be a year of snacks. NRA. Retrieved from www.qsrmagazine. com/news/nra-2008-forecast-coverage-predicts-2008-be-year-snacks

Clay, J. (2004). World agriculture and the environment: a commodity by commodity guide to impacts and practices. Washington: Island Press.

Cooper, H. M. (1989). Interating research: a guide for literature reviews. Newbury Park: Sage.

Cuéllar, A. D., \& Webber, M. E. (2010). Wasted food, wasted energy: the embedded energy in food waste in the United States. Environmental Science \& Technology, 44(16), 6464-6469. http://dx.doi.org/10.1021/ es100310d. PMid:20704248.

Environmental Protection Agency - EPA. (2011). Basic information about food waste. Retrieved from www.epa.gov/sustainable-managementfood/sustainable-management-food-basics\#what

Environmental Protection Agency - EPA. (2014). Advancing sustainable materials management. Retrieved from www.epa.gov/sites/production/ files/2016-11/documents/2014_smmfactsheet_508.pdf

Evans, D. (2012). Binning, gifting and recovery: The conduits of disposal in household food consumption. Environment and Planning. D, Society \& Space, 30(6), 1123-1137. http://dx.doi.org/10.1068/d22210.

Ferreira, J. R. S., \& Santos, E. F. C. (2016). Brazil recycler: applying production engineering in fry oil recycling in Mato Grosso - MT. In Anais do $9^{\circ}$ Encontro Nacional de Engenharia de Producão (ENEGEP). Rio de Janeiro: ABEPRO.

Flammini, A., Scialabba, N. E. H., Hoogeveen, J., Iweins, M., Tubiello, F., Peiser, L., \& Batello, C. (2013). Food wastage footprint: impacts on natural resources. Rome: Natural Resources Management and Environment Department, Food and Agriculture Organization. Retrieved from www.fao.org/3/i3347e/i3347e.pdf 
Food and Agriculture Organization - FAO. (2013). Food Wastage Footprint: Impacts on natural resources. Retrieved from www.fao. org/3/i3347e/i3347e.pdf.

Garnett, T. (2011). Where are the best opportunities for reducing greenhouse gas emissions in the food system (including the food chain)? Food Policy, 36(1), S23. http://dx.doi.org/10.1016/j. foodpol.2010.10.010.

Gjerris, M., \& Gaiani, S. (2013). Household food waste in Nordic countries: estimations and ethical implications. Nordic Jounal of Appliled Ethics, 7(1), 6-23. http://dx.doi.org/10.5324/eip.v7i1.1786.

Godfray, J. R., Beddington, J. R., Crute, I. R., Haddad, L., Lawrence, D., Muir, J. F., Pretty, J., Robinson, S., Thomas, S. M., \& Toulmin, C. (2010). Food security the challenge of feeding 9 bilions people. Science, 327(5967), 812. http://dx.doi.org/10.1126/science.1185383. PMid:20110467.

Graham-Rowe, E., Jessop, D. C., \& Sparks, P. (2014). Identifying motivations and barriers to minimising household food waste. Resources, Conservation and Recycling, 84, 15-23. http://dx.doi. org/10.1016/j.resconrec.2013.12.005.

Grandhi, B., \& Appaiah Singh, J. A. (2016). What a waste! A study of food wastage behavior in Singapore. Journal of Food Products Marketing, 22(4), 471-485. http://dx.doi.org/10.1080/10454446.2014.885863.

Gustavsson, J., Cederberg, C., Sonesson, U., Otterdijk, R., \& Meybeck, A. (2011). Global food losses and food waste. Rome: Food and Agriculture Organization. Retrieved from www.fao.org/3/a-i2697e.pdf

Hu, H.-H., Parsa, H. G., \& Self, J. (2010). The dynamics of green restaurant patronage. Cornell Hospitality Quarterly, 51(3), 344-362. http://dx.doi.org/10.1177/1938965510370564.

Hynds, E. J., Brandt, V., Burek, S., Jager, W., Knox, P., Parker, J. P., Schwartz, L., Taylor, J., \& Zietlow, M. (2014). A maturity model for sustainability in new product development. Research Technology Management, 57(1), 50-57. http://dx.doi.org/10.5437/08956308X5701143.

Kallbekken, S., \& Sælen, H. (2013). Nudging hotel guests to reduce food waste as a win win environmental measure. Economics Letters, 119(3), 325-327. http://dx.doi.org/10.1016/j.econlet.2013.03.019.

Lagorio, A., Pinto, R., \& Golini, R. (2018). Food waste reduction in school canteens: Evidence from an Italian case. Journal of Cleaner Production, 199, 77-84. http://dx.doi.org/10.1016/j.jclepro.2018.07.077.

Lebersorger, S., \& Schneider, F. (2011). Discussion on the methodology for determining food waste in household waste composition studies. Waste Management, 31(9-10), 1924-1933. http://dx.doi.org/10.1016/j. wasman.2011.05.023. PMid:21705207.

Llach, J., Perramon, J., Almeida, M. M. A., \& Bagur-Femenías, L. (2013). Joint impact of quality and environmental practices on firm performance in small service businesses: an empirical study of restaurants. Journal of Cleaner Production, 44, 96-104. http:// dx.doi.org/10.1016/j.jclepro.2012.10.046.

Lopes, M. L., \& Fonseca, V. V. (2013). Estudo do manejo dos resíduos de um restaurante institucional da região sul fluminense. Interbio, 7(1), 47-53.

Lustosa, M. M. A. (2011). A produção mais limpa no processo de refeições coletivas: um estímulo à inovação. In Anais do XXXI Encontro Nacional de Engenharia de Produção. Rio de Janeiro: ABEPRO.

Marreiros, C., \& Ness, M. (2009). A conceptual framework of consumer food choice behaviour. Évora: CEFAGE-UE, Universidade de Évora. Retrieved from www.cefage.uevora.pt/en/content/download/1715/22411/ version/1/file/2009_06.pdf

Martinelli, S. S. (2011). Development of method of nutritional quality, sensory, regulatory and sustainability in meat supply in meal producing units: the example of beef (Master's thesis). Universidade Federal de
Santa Catarina, Florianópolis. Retrieved from www.repositorio.ufsc. br/xmlui/handle/123456789/95250

Martinelli, S. S., Cavalli, S. B., Pires, P. P., Proença, L. C., \& Proença, R. P. C. (2012). Water consumption in meat thawing under running water: sustainability in meal production. Journal of Culinary Science \& Technology, 10(4), 311-325. http://dx.doi.org/10.1080/15428052 .2012.728982.

Martins, A. M. (2015). Sustentabilidade ambiental em unidades de alimentação e nutrição coletivas de Santa Catarina (Master's thesis). Universidade Federal de Santa Catarina, Florianópolis. Retrieved from www.repositorio.ufsc.br/xmlui/bitstream/ handle/123456789/135679/334982.pdf? sequence $=1 \&$ isAllowed $=y$

Martins, E. N., Herculano, R. I., \& Santos, M. C. T. (2016). The importance of health, ergonomics and safety in a collective or commercial food production environment. Electronic Connection, 13(1), 9.

Oliveira, S. M. (1984). Applications and limitations of bibliometric processes. Brazilian Journal of Library and Documentation, 5(17), 43-54.

Ornelas, L. H. (2006). Técnica dietética: seleção e preparo de alimentos. São Paulo: Atheneu.

Painter, K., Thondhlana, G., \& Kua, H. W. (2016). Food waste generation and potential interventions at Rhodes University, South Africa. Waste Management, 56, 491-497. http://dx.doi.org/10.1016/j. wasman.2016.07.013. PMid:27450431.

Papargyropoulou, E., Lozano, R., Steinberger, J., Wright, N., \& Ujang, Z. (2014). The food waste hierarchy as a framework for the management of food surplus and food waste. Journal of Cleaner Production, 76, 106-115. http://dx.doi.org/10.1016/j.jclepro.2014.04.020.

Parfitt, J., Barthel, M., \& Macnaughton, S. (2010). Food waste within food supply chains: quantification and potential for change to 2050 . Philosophical Transactions of the Royal Society of London. Series B, Biological Sciences, 365(1554), 3065-3081. http://dx.doi.org/10.1098/ rstb.2010.0126. PMid:20713403.

Parizeau, K., Von Massow, M., \& Martin, R. (2015). Household-level dynamics of food waste production and related beliefs, attitudes, and behaviours in Guelph, Ontario. Waste Management, 35, 207-217. http://dx.doi.org/10.1016/j.wasman.2014.09.019. PMid:25445261.

Pierre, L., Souza, W. J., \& Bitencourt, L. (2013). Sustainability in the production of meals in an institutional restaurant in the municipality of Ouro Preto-MG. Belo Horizonte: Instituto Federal de Minas Gerais.

Pinto, R. S., Pinto, R., Melo, F. F. S., Campos, S. S., \& Cordovil, C. M. (2018). A simple awareness campaign to promote food waste reduction in a University canteen. Waste Management, 76, 28-38. http://dx.doi.org/10.1016/j.wasman.2018.02.044. PMid:29503053.

Pirani, S. I., \& Arafat, H. A. (2016). Reduction of food waste generation in the hospitality industry. Journal of Cleaner Production, 132, 129145. http://dx.doi.org/10.1016/j.jclepro.2015.07.146.

Proença, R. P. C. (2000). Technological Innovation in the production of collective food (2nd ed). Florianópolis: Insular.

Proença, R. P. C., Sousa, A. A., Veiros, M. B., \& Hering, B. (2005). Qualidade nutricional e sensorial na produção de refeições (pp. 4-17). Florianópolis: UFSC.

Quested, T. E., Marsh, E., Stunell, D., \& Parry, A. D. (2013). Spaghetti Soup: the complex world of food waste behaviours. Resources, Conservation and Recycling, 79, 43-51. http://dx.doi.org/10.1016/j. resconrec.2013.04.011.

Rand, D. G., \& Nowak, M. A. (2013). Human cooperation. Trends in Cognitive Sciences, 18(8), 413425. PMid:23856025.

Reinders, M. J., Huitink, M., Dijkstra, S. C., Maaskant, A. J., \& Heijnen, J. (2017). Menu-engineering in restaurants - adapting portion sizes 
on plates to enhance vegetable consumption: a real-life experiment. The International Journal of Behavioral Nutrition and Physical Activity, 14(1), 41. http://dx.doi.org/10.1186/s12966-017-0496-9. PMid:28424081.

Rubio-Andrada, L., Del Mar Alonso-Almeida, M., \& Rodríguez-Antón, J. M. (2011). Motivations and impacts in the firm and stakeholders of quality certification: evidence from small and medium-sized service enterprises. Journal of Total Quality Management \& Business Excellence, 22(8), 833-852. http://dx.doi.org/10.1080/14783363.20 11.593858 .

Schanes, K., Dobernig, K., \& Gözet, B. (2018). Food waste matters - A systematic review of household food waste practices and their policy implications. Journal of Cleaner Production, 182, 978-991. http:// dx.doi.org/10.1016/j.jclepro.2018.02.030.

Schneider, F. (2013). Review of food waste prevention on an international level. Proceedings of the Institution of Civil Engineers - Waste and Resource Management, 166(4), 187-203. doi:http://dx.doi.org/10.1680/ warm.13.00016.

Short, T., Lee-Mortimer, A., Luttropp, C., \& Johansson, G. (2012). Manufacturing, sustainability, ecodesign and risk: lessons learned from a study of Swedish and English companies. Journal of Cleaner Production, 37, 342-352. http://dx.doi.org/10.1016/j.jclepro.2012.07.037.

Soares, I. C. C., Silva, E. R., Piore, S. E., Ribeiro, R. C. L., Pereira, M. M. L. S., \& Pinehiro, H. M. (2011). Quantification and analysis of the cost of food wastage in the cafeterias of a large company.
Nutrition Magazine, 24, 593-604. http://dx.doi.org/10.1590/S141552732011000400008.

Strasburg, V. J., \& Jahno, V. D. (2017). Application of eco-efficiency in the assessment of raw materials consumed by university restaurants in Brazil: a case study. Journal of Cleaner Production, 161, 178-187. http://dx.doi.org/10.1016/j.jclepro.2017.05.089.

Strasburg, V. J., \& Pereira, D. C. K. (2014). Environmental assessment instrument in a university restaurant. In Proceedings of the IX International Symposium on Environmental Quality. Geneva: ISHS.

U.S. Bureau of Labor Statistics - BLS. (2010). Consumer expenditures in 2008. Washington: BLS. Retrieved from www.bls.gov/cex/csxann08.pdf

Vaz, C. S. (2011). Restaurants: controlling costs and increasing profits. Brasília: Metha.

Wansink, B., \& Van Ittersum, K. (2013). Portion size me: plate-size induced consumption norms and win-win solutions for reducing food intake and waste. Journal of Experimental Psychology. Applied, 19(4), 320-332. http://dx.doi.org/10.1037/a0035053. PMid:24341317.

Watson, M., \& Meah, A. (2013). Food and waste: negotiating conflicting social anxieties into the practices of provisioning. The Sociological Review, 60(S2), 102-120.

WRAP.(2016). Consumer Behaviours, Attitudes \& Knowledge towards Food \& Waste. Retrieved from www.wrap.org.uk/sites/files/wrap/ CFWP\%20Survey\%20Spring\%202017.pdf. 